\title{
Alteration in endothelial permeability occurs in response to the activation of PAR2 by factor Xa but not directly by the TF-factor VIla complex
}

PAR2 activation increases EC permeability

Naima E. Benelhaja ${ }^{\mathrm{a}}$ Anthony Maraveyas ${ }^{\mathrm{a}}$, Sophie Featherby ${ }^{\mathrm{b}}$, Mary EW Collier ${ }^{\mathrm{c}}$, Miriam J Johnson $^{\mathrm{a}}$, Camille Ettelaie $\mathrm{b}^{\mathrm{b}^{\star}}$

aDivision of Cancer-Hull York Medical School, University of Hull, Cottingham Road, Hull, HU6 7RX, UK, biomedical Section, School of Life Sciences, University of Hull, Cottingham Road, Hull, HU6 7RX, UK. 'Department of Cardiovascular Sciences, University of Leicester, Glenfield General Hospital, Leicester, LE3 9QP, UK.

${ }^{*}$ Correspondence to $\mathrm{Dr}$ Camille Ettelaie, Biomedical Section, Department of Biological Sciences, University of Hull, Cottingham Road, Hull, HU6 7RX, UK

Email: C.Ettelaie@hull.ac.uk

Tel: $+44(0) 1482-465528$

Fax: $+44(0) 1482-465458$

ORCID number: 0000-0002-6121-5262

Keywords - Endothelial permeability, Protease activated receptor 2, Coagulation factor Xa, Direct oral anticoagulants, Microvesicles. 


\section{Abstract}

Alterations in the endothelial permeability occur in response to the activation of coagulation mechanisms in order to control clot formation. The activation of the protease activated receptors (PAR) can induce signals that regulate such cellular responses. PAR2 is a target for the coagulation factor $\mathrm{Xa}(\mathrm{fXa})$ and tissue factor-factor VIla (TF-fVIla) complex. By measuring the permeability of dextran blue across endothelial monolayer, we examined the mechanisms linking coagulation and endothelial permeability. Activation of PAR2 using the agonist peptide (PAR2-AP) resulted in increased permeability across the monolayer and was comparable to that obtained with VEGF at 60 min. Incubation of cells with activated factor Xa ( $\mathrm{fXa}$ ) resulted in an initial decrease in permeability by $30 \mathrm{~min}$, but then significantly increased at $60 \mathrm{~min}$. These responses required fXa activity, and were abrogated by incubation of the cells with a PAR2-blocking antibody (SAM11). Activation of PAR2 alone, or inhibition of PAR1, abrogated the initial reduction in permeability. Additionally, inclusion of Rivaroxaban $(0.6 \mu \mathrm{g} / \mathrm{ml})$ significantly inhibited the response to fXa. Finally, incubation of the endothelial monolayers up to $2 \mathrm{~h}$ with TF-containing microvesicles derived from MDA-MB-231 cells, in the presence or absence of $\mathrm{fVIIa}$, did not influence the permeability across the monolayers. In conclusion, fXa but not TF-fVIIa is a noteworthy mediator of endothelial permeability. The rapid initial decrease in permeability requires PAR2 and PAR1 which may act to constrain bleeding. The longer-term response is mediated by PAR2 with increased permeability, presumably to enhance clot formation at the site of damage. 


\section{Introduction}

Under physiological conditions, the endothelial layer acts as one of the regulators of the haemostatic mechanism, acting as a barrier between the blood and the underlying thrombogenic tissue. However, this barrier is dynamic and is regulated to conform to the requirements of the local vasculature. Alterations in endothelial permeability are essential in the maintenance of the correct homeostatic functions but also, are often central in the pathogenesis of inflammatory and vascular disorders. Following injury, the responses by the vasculature limits blood flow and then allows seepage into the sub-endothelial layer. Protease activated receptors are G-protein coupled receptors which act as sensors for the presence of active proteases, in particular those that are involved in the coagulation mechanism [1,2]. The endothelial cells express PAR1 and PAR2 which mediate numerous outcomes that include changes to endothelial permeability [3-5]. PAR2 signalling is induced following the proteolysis by coagulation factor Xa (fXa), tissue factor-factor VIla (TF-fVIIa) complex as well as by trypsin I, II and IV, tryptase, acrosin, granzyme A and kallikrein 2, 4, 6 and 14 , in a canonical manner, and by elastase, proteinase 3 and cathepsins $\mathrm{G}$ and $\mathrm{S}$ in a non-canonical system [6,7]. The activation of PAR2 has also been associated with inflammatory responses during chronic disorders [2,8] and suggested as a cause of vascular complications associated with various diseases [4,9].

Endothelial cells are connected to each other by a complex set of junction proteins [1013]. Under normal conditions, inter-endothelial junctions open to permit the passage of molecules and surveillance cells in a dynamic and size-selective manner [14-16]. Moreover, a number of inflammatory agents including thrombin and VEGF, are able to stretch out these junctions permitting contact between plasma and the sub-endothelial layer [17-19]. It has been shown that endothelial cells respond to coagulation by altering the vascular permeability [20]. However, little is known of the endothelial responses under conditions of coagulation, when the proteases are simultaneously generated. Furthermore, the overall response is likely to also be dependent on the magnitude of coagulation activation, which in 
turn would be dependent on the extent of the injury incurred. The role of PAR2 in the alteration of vascular permeability has not been defined. Current reports equally ascribe the activation of PAR2 signalling to increases in endothelial permeability $[8,21,22]$, and refute such a response $[23,24]$. In addition, it has been suggested that PAR2 acts in conjunction with PAR1 to desensitize subsequent cellular responses to thrombin [5]. In this study we have examined the ability of fXa and TF-fVIla to influence the permeability of endothelial monolayers. In addition, by inhibiting fXa activity and blocking PAR2 activation, the role of these proteins in the regulation of endothelial permeability is further clarified.

\section{Material and methods}

\section{Cell culture and endothelial-barrier permeability assay}

Human coronary artery primary endothelial cells (HCAEC) and human dermal bloodmicrovascular endothelial cells (HDBEC), devoid of endogenous TF were cultured in MV media containing $5 \%(\mathrm{v} / \mathrm{v})$ foetal calf serum (FCS) and growth supplements (PromoCell, Heidelberg, Germany). MDA-MB-231 breast cancer cell line (ATCC, Teddington, UK) was cultured in DMEM, containing 10\% (v/v) FCS.

The in vitro endothelial barrier assay was adapted by modification of a previously described procedure [5]. Transwell polyester membrane inserts $(3.0 \mu \mathrm{m}$ pore size; Thermo Scientific, Warrington, UK) were coated with $0.5 \%(w / v)$ gelatin (Sigma Chemical Company Ltd, Poole, UK) and incubated for $2 \mathrm{~h}$ prior to usage. Cells $\left(6 \times 10^{4}\right)$ were seeded out and cultured in complete endothelial cell medium and propagated for 4 days to obtain confluent monolayers. The permeability of the monolayers was assessed under test conditions without any stimulus and found to remain uncompromised for $>2 \mathrm{~h}$. On the day of the experiments, the monolayers were washed twice with phosphate buffered saline (PBS). The cells were then incubated for $1 \mathrm{~h}$ in with equal volumes of serum-free endothelial medium at the upper and lower chambers. Blue dextran $\mathrm{MW} 4 \times 10^{4}$ (Sigma) was diluted to a final concentration of 
$1 \mu \mathrm{g} / \mathrm{ml}$ in PBS was then added to the upper chamber of each Transwell. Any test-chambers with apparent leakages at the start of the experiment were excluded. The test reagents were then added to the upper chambers and incubated at $37^{\circ} \mathrm{C}$ for up to $120 \mathrm{~min}$. Aliquots of the media $(200 \mu \mathrm{l})$ were removed from the bottom chamber and the absorption measured at 584 $\mathrm{nm}$.

\section{Preparation of test reagents}

Rivaroxaban was obtained as pure compounds from Bayer (Leverkusen, Germany), dissolved in dimethyl sulfoxide (DMSO) and diluted in PBS to $4 \mathrm{mg} / \mathrm{ml}$ working stock solutions. Appropriate controls using similarly diluted DMSO were used alongside, as controls. The final concentrations of the Rivaroxaban were optimised against purified fXa beforehand to ensure maximal inhibition. Vascular endothelial growth factor (VEGF)-A (TCS Cellworks/Caltag Medsystems Ltd, Buckingham, UK) was diluted to $25 \mathrm{ng} / \mathrm{ml}$ final concentration in the base culture medium. Protease activated receptor 2-agonist peptide (PAR2-AP; SLIGKV) and PAR1-AP (TFLLR) were synthesised (Severn Biotech Ltd, Kidderminster, UK) and used at a final concentration of $20 \mu \mathrm{M}$ [25]. Coagulation factors Xa and VIla (Enzyme Research Laboratories, Swansea, UK) were diluted stepwise to the required concentrations (10 $\mathrm{nM}$ and $5 \mathrm{nM}$ ) in the base culture medium. Recombinant TF (Innovin thromboplastin reagent; Dade Behring, Deerfield, USA) was used at a final concentration of $1 \mathrm{U} / \mathrm{ml}(1.3 \mathrm{ng} / \mathrm{ml})$. Blocking antibodies for PAR2 (SAM11) and PAR1 (ATAP2) were obtained from Santa Cruz Biotechnology (Heidelberg, Germany) and were incubated with the cells at $20 \mu \mathrm{g} / \mathrm{ml}$ to prevent the activation of PAR2 and PAR1 respectively.

\section{Preparation and quantification of the TF-containing microvesicles}

MDA-MB-231 cells were propagated in $25 \mathrm{~cm}^{2}$ flasks. To generate the TF-containing microvesicles, the cells were washed and adapted to DMEM serum-free medium, for $2 \mathrm{~h}$. The released microvesicles were then prepared from the conditioned media by ultracentrifugation according to described procedures [26]. The functional density of the 
released of microvesicles was determined using the Zymuphen MP-assay kit (Hyphen BioMed/Quadratech, Epsom, UK) and the microvesicle density determined from the standards provided by the kit. The released microvesicle-associated TF antigen was measured using the Quantikine TF-ELISA kit (R\&D Systems, Abingdon, UK) according to the manufacturer's instructions. Cell surface TF antigen was measured in situ using an ELISA-based procedure a previously described $[27,28]$.

\section{Chromogenic activity assays}

Thrombin generation potential of the purified microvesicles was confirmed using a twostage chromogenic thrombin generation assay as before [27]. The activity of fXa was measured using a chromogenic fXa substrate (0.2 mM; Hyphen).

\section{$\underline{\text { Statistical analysis }}$}

All data represent the calculated mean values from the number of experiments stated in each figure legend \pm the calculated standard error of the mean. Statistical analysis was carried out using the Statistical Package for the Social Sciences (SPSS Inc. Chicago, USA). Significance was determined using one-way ANOVA (analysis of variance) and Tukeys honesty significance test or where appropriate, by paired t-test.

\section{Results}

To ensure that the endothelial monolayers were not affected for the duration of the assay by the lack of serum, the presence of blue dextran or the inclusion of DMSO, initially the Transwell-monolayers were monitored over $2 \mathrm{~h}$ and confirmed to remain intact (not shown). Incubation of the monolayer without any stimulus resulted a gradual increase in the transfer of dextran blue as expected, but this was not significant over the period of analysis (Fig. 1) and therefore deemed to be a stable model.

Activation of PAR2 by $\mathrm{fXa}$ alters the permeability across the endothelial monolayer

The activation of both HCAEC and HDBEC using PAR2-AP resulted in increased 
permeability within 60 min but was less than that induced by VEGF (Fig. 1). No further increase in the permeability was detected after this time point. Furthermore, incubation of cells with PAR1-AP did not result in any significant change in the permeability of endothelial monolayer which in agreement with some [5], but contradictory to other reports [24]. Incubation of HCAEC and HDBEC monolayers with $\mathrm{fXa}(10 \mathrm{nM})$ prevented the change in the permeability across the monolayers and therefore, resulted in a relative decrease when compared to the untreated sample at the same time point (Fig. 2). This was replaced by a significant increase in the leakage of blue dextran (80\% and $92 \%$ increase) across HCAEC and HDBEC monolayers respectively, at $60 \mathrm{~min}$ post-addition of $\mathrm{fXa}$. Incubation of endothelial monolayers with a lower concentration of $\mathrm{fXa}(5 \mathrm{nM})$ did not result in the initial reduction in permeability at $30 \mathrm{~min}$ and the ensuing increase in permeability was not significant.

The induction of endothelial permeability requires fXa proteolytic activity

Rivaroxaban is direct oral anticoagulant which function through binding and directly inhibiting $\mathrm{fXa}$. To ensure complete inhibition of $\mathrm{fXa}$, samples of $\mathrm{fXa}$ were pre-incubated with therapeutic and sub-therapeutic concentrations of Rivaroxaban $(0.6$ and $0.06 \mu \mathrm{g} / \mathrm{ml})$ prior to measuring the residual fXa activity using a fXa-chromogenic substrate (Fig. 3). In order to examine the requirement for the proteolytic function of $\mathrm{fXa}$, endothelial monolayers were incubated with fXa $(10 \mathrm{nM})$ and also in the presence of Rivaroxaban $(0.06$ and $0.6 \mu \mathrm{g} / \mathrm{ml})$. Inclusion of Rivaroxaban $(0.6 \mu \mathrm{g} / \mathrm{ml})$ significantly inhibited the response of the endothelial monolayer to fXa (92\% inhibition) (Fig. 4A). Rivaroxaban also prevented the initial reduction in permeability at $30 \mathrm{~min}$ (Fig. 4B).

The induction of endothelial permeability is mediated through PAR2 activation

To determine if the observed changes in permeability were as a consequence of the proteolytic activation of PAR2 by $\mathrm{fXa}$, sets of HCAEC and HDBEC were pre-incubated with blocking antibodies to PAR2 and PAR1. Inhibition of PAR2 using SAM11 antibody prior to 
addition of $\mathrm{fXa}(10 \mathrm{nM})$ abrogated all changes in permeability of the monolayer in response to fXa (Fig. 5). Activation of cells with fXa in the presence of PAR1 blocking antibody (ATAP2) resulted in the omission of the initial reduction in permeability. However, the increase in permeability at 60 min was not significantly altered when compared to fXa alone.

\section{Factor Xa but not TF-fVIla complex is capable of inducing endothelial permeability}

In addition to fXa, the TF-fVIla complex is known to be capable of activating PAR2 directly. Therefore, the possibility that TF-containing microvesicles may also be capable of increasing the endothelial permeability through PAR2 activation was explored. TF-containing microvesicles were isolated from MDA-MB-231 cells and confirmed to posses significant thrombin generation potential at $10 \mathrm{nM}$. Thereafter, endothelial monolayers were incubated with TF-containing microvesicles (10 $\mathrm{nM}$ final concentration), or alternatively with recombinant TF $(1 \mathrm{U} / \mathrm{ml})$, in the presence or absence of additional fVIla $(5 \mathrm{nM})$. Incubation of HCAEC for 60 or 120 min with TF-containing microvesicles, or recombinant TF was largely ineffective in increasing the permeability of the monolayers and remained unaltered on inclusion of fVIla (Fig. 6A). Finally, the inclusion of both fXa and fVIla with either the microvesicles or recombinant TF did not enhance the permeability of the endothelial monolayers, beyond that observed with fXa alone (Fig. 6B).

\section{Discussion}

The ability of the vasculature to determine the nature and magnitude of a stimulus is essential for the appropriate and proportionate response. The vascular response to injury include rapid changes to blood flow to reduce the loss of blood, followed by increased contact with the sub-endothelial layer, in order for the formation of a stable and effective clot [29-32]. In agreement with this hypothesis the incubation of the endothelial monolayers with fXa resulted in an initial reduction in permeability followed by significantly higher levels of leakage across to the lower chamber. Interestingly, incubation of endothelial monolayers 
with sub-optimal levels of $\mathrm{fXa}(5 \mathrm{nM})$ did not produce any response while at $10 \mathrm{nM}$, the enzyme produced full response in the cells. The magnitude of increased permeability at 60 min, following activation with $\mathrm{fXa}(10 \mathrm{nM})$ was higher than that obtained with PAR2-AP. Furthermore, the response to PAR2-AP did not produce the initial tightening of the endothelial layer at 30 min. Activation of $\mathrm{fX}$ within the blood is initiated by the TF-fVIIa complex and therefore the relatively lower amounts of fXa generated by the extrinsic pathway may be incapable of causing vascular permeability. Conversely, full activation of the coagulation involving the intrinsic pathway can convert a large quantity of the available $f X$ at the locality of the injury. Therefore, it is plausible that under these conditions the adaptations in the permeability of the endothelial layer to allow contact between plasma and the subendothelial layer, becomes an essential step in the completion and strengthening of the clot. This mechanism appears to be dependent on the proteolytic activity of fXa and was significantly diminished in the presence of Rivaroxaban. As stated above, while some studies report that the activation of PAR2 signalling promotes endothelial permeability $[8,21,22]$, others did not find a response [23,24]. Furthermore, Feistritzer and Riewald [5] suggested that PAR1 and PAR2 act in conjunction to desensitize endothelial response to further activation. Our data indicate that the activation of PAR2 appears to be a major inducer of permeability and may participate in the original reduction endothelial tightness. A recent report has shown that the activation of PAR2 can disrupt cellular tight junctions through the activation of p38 MAPK alone [33]. However, concurrent activation of ERK1/2 and Akt pathways in response to PAR2 activation may occur independently [33,34]. Furthermore, some PAR2 signalling appears to be dose dependent even when using the activating peptide [35]. These data are in accord with our finding that the induction of PAR2 using the activating peptide results in the activation of p38 MAPK the magnitude of which can further be modulated by other factors including the presence of TF [36]. Moreover, the activation of PAR2 alone using the agonist peptide did not produce the initial tightening of the endothelial layer at 30 min. Consequently, PAR1 appears to be an essential contributor to the initial reduction in permeability. Therefore, the responses of PAR2, in conjunction with 
PAR1 appear to constitute a means of converting the signal arising from fXa into the converse but canonical and time-dependent modifications in endothelial permeability. It has been recognised that while PAR2 constitutes the main receptor for fXa induced signalling, PAR1 also acts as a minor target for $\mathrm{fXa}$ [37] and may be involved in fXa signalling [38]. The protective influence of PAR1 [5,39.40] in thrombin-mediated signalling, on endothelial function has been documented [4,5]. Moreover, the ability of PAR1 to induce endothelial permeability is known [41]. However, thrombin appears to influence vascular permeability through multiple mechanisms including direct signalling, by influencing other cells through the nitric oxide-mediated pathways. Moreover, the outcomes of response to thrombin appear to be both cell-specific and target-selective, affecting various different proteins within the cellular tight junction [42]. In addition, some of the differences in the outcomes appears to arise from the requirement for cell-surface effectors such as APC or PAR3 $[4,43]$ although some reports dispute a direct role for PAR3 in the response to PAR1 or the expression of PAR4 on some endothelial cells [44]. Finally, it has been suggested that the magnitude of activation of PAR1 is amplified by proteolytic action of thrombin, in comparison to for example by PAR1-activating peptide $[45,46]$. Therefore, we are not able to present a conclusive explanation for the lack of alterations in permeability in response to PAR1activating peptide. Additionally, the focus of our study has been the role of fXa as a first messenger in regulating the induction of endothelial permeably in response to the activation of coagulation. Consequently, the discussions on the multiple roles of thrombin and the magnitude of PAR1 activation, together with the multiple second messengers and pathways involved in PAR signalling $[3,4]$ is beyond the scope of our study. Consequently, the outcome of PAR1 activation was not further pursued in this study. However, in addition to the contribution from PAR1, co-operative signalling from other receptors such as EPCR $[53,54]$ may also contribute to PAR2 signalling and require clarification.

The initial reduction and the subsequent increase in permeability proposes a regulatory process to control bleeding. However, following repeated injury, or during long-term 
presence of the inflammatory stimuli, these mechanisms may become defective and even detrimental. The expression of TF is a hallmark of chronic inflammatory conditions but TFfVIla complex is not always fully active and can exist in an encrypted or partially active format [47-52]. In our experiments, either recombinant TF, or TF contained within microvesicles derived from a cell line did not affect the endothelial permeability. Intriguingly, the inclusion of fVIla with the TF also was not capable of eliciting similar responses to fXa. Previously we showed that TF-containing microvesicles from MDA-MB-231 cells begin to be assimilated within the endothelial cell membrane within 30 min of incubation [55]. To ensure sufficient intervals cell permeability was analysed at 60 and 120 min following induction. This finding suggest that the presence of TF per se is not sufficient to induce such alterations in permeability which in turn may escalate into thrombus formation $[56,57]$. Moreover, this observation questions the role of plasma seepage arising from endothelial permeability, as the main cause of distal thromboembolism, for example in cancer patients who have detectable amounts of circulating TF-containing microvesicles. However, the possibility of the involvement of a ternary complex TF-fVIIa-fXa is not dismissed and it is feasible that once sufficient $\mathrm{fXa}$ is generated by the coagulation mechanism, the induction of permeability may be enhanced by TF-fVIla-fXa complex formation. Regardless, the use of anti-fXa agents such as direct oral anticoagulants may be effective in limiting the vascular permeability and oedema formation.

The crosstalk between the coagulation mechanism and the vasculature ensures correct haemostasis following injury. Among the components involved in this communication is PAR2 which responds to generated proteases. This study indicates that the activation of PAR2 by the proteolytic action of $\mathrm{fXa}$ but not TF-fVIla complex, mediates endothelial responses that initially result in the reduction of vascular permeability, and subsequently promote increased contact between blood plasma and the sub-endothelial layer.

\section{Authors' contributions}

The study was designed by $A M, M C$ and $C E$, and the experimental work carried out by NB 
and SF. The data were evaluated by NB, AM, MJ and CE and the manuscript was prepared by NB and CE.

\section{Acknowledgements}

Rivaroxaban was provided by Bayer as pure compound and is acknowledged.

\section{References}

1. Nieman MT. Protease-activated receptors in hemostasis. Blood. 2016;128(2):169-177. doi: 10.1182/blood-2015-11-636472.

2. Rothmeier AS, Ruf W. Protease-activated receptor 2 signaling in inflammation. Semin Immunopathol. 2012;34(1):133-149. doi: 10.1007/s00281-011-0289-1.

3. McCoy KL, Traynelis SF, Hepler JR. PAR1 and PAR2 couple to overlapping and distinct sets of $G$ proteins and linked signaling pathways to differentially regulate cell physiology. Mol Pharmacol. 2010;77(6):1005-1015. doi:10.1124/mol.109.062018.

4. Alberelli MA, De Candia E. Functional role of protease activated receptors in vascular biology. Vascul Pharmacol. 2014;62(2):72-81. doi:10.1016/j.vph.2014.06.001.

5. Feistritzer C, Lenta R, Riewald M. Protease-activated receptors- 1 and -2 can mediate endothelial barrier protection: role in factor $\mathrm{Xa}$ signaling. $\mathrm{J}$ Thromb Haemost. 2005;3(12):2798-2805.

6. Zhao P, Metcalf M, Bunnett NW. Biased signaling of protease-activated receptors. Front Endocrinol (Lausanne). 2014;5:67. doi: 10.3389/fendo.2014.00067.

7. Hollenberg MD, Mihara K, Polley D, Suen JY, Han A, Fairlie DP, Ramachandran R. Biased signalling and proteinase-activated receptors (PARs): targeting inflammatory disease. Br J Pharmacol. 2014;171(5):1180-1194. doi: 10.1111/bph.12544.

8. Vergnolle N, Hollenberg MD, Sharkey KA, Wallace JL. Characterization of the inflammatory response to proteinase-activated receptor-2 (PAR2)-activating peptides in the rat paw. Br J Pharmacol. 1999;127(5):1083-1090.

9. Bucci M, Roviezzo F, Cirino G. Protease-activated receptor-2 (PAR2) in cardiovascular system. Vascul Pharmacol. 2005;43(4):247-253.

10. Zhang R, Ge J. Proteinase-Activated Receptor-2 Modulates Ve-Cadherin Expression to Affect Human Vascular Endothelial Barrier Function. J Cell Biochem. 2017;118(12):4587-4593. doi: 10.1002/jcb.26123. 
11. Van Itallie CM, Anderson JM. Architecture of tight junctions and principles of molecular composition. Semin Cell Dev Biol. 2014;36:157-165. doi: 10.1016/j.semcdb.2014.08.011.

12. Claesson-Welsh L. Vascular permeability--the essentials. Ups J Med Sci. 2015;120(3):135-143. doi: 10.3109/03009734.2015.1064501.

13. Vestweber D. Relevance of endothelial junctions in leukocyte extravasation and vascular permeability. Ann N Y Acad Sci. 2012;1257:184-92. doi: 10.1111/j.17496632.2012.06558.x.

14. Sukriti S, Tauseef $M$, Yazbeck $P$, Mehta D. Mechanisms regulating endothelial permeability. Pulm Circ. 2014;4(4):535-551. doi: 10.1086/677356.

15. Mehta $D$, Malik AB. Signaling mechanisms regulating endothelial permeability. Physiol Rev. 2006;86(1):279-367.

16. Chavez A, Smith M, Mehta D. New insights into the regulation of vascular permeability. Int Rev Cell Mol Biol. 2011;290:205-248. doi: 10.1016/B978-0-12-386037-8.00001-6.

17. Esser S, Lampugnani MG, Corada M, Dejana E, Risau W. Vascular endothelial growth factor induces VE-cadherin tyrosine phosphorylation in endothelial cells. J Cell Sci. 1998;111(Pt 13):1853-1865.

18. Bates DO, Harper SJ. Regulation of vascular permeability by vascular endothelial growth factors. Vascul Pharmacol. 2002;39(4-5):225-237.

19. Chidlow JH Jr, Sessa WC. Caveolae, caveolins, and cavins: complex control of cellular signalling and inflammation. Cardiovasc Res. 2010 1;86(2):2192-25. doi: 10.1093/cvr/cvq075.

20. Lupu C, Westmuckett AD, Peer G, Ivanciu L, Zhu H, Taylor FB Jr, Lupu F. Tissue factordependent coagulation is preferentially up-regulated within arterial branching areas in a baboon model of Escherichia coli sepsis. Am J Pathol. 2005;167(4):1161-72. PubMed PMID: 16192650.

21. Sawada S, Ono Y, Egashira Y, Takagi T, Tsuruma K, Shimazawa M, Iwama T, Hara H. In Models of Intracerebral Hemorrhage, Rivaroxaban is Superior to Warfarin to Limit Blood Brain Barrier Disruption and Hematoma Expansion. Curr Neurovasc Res. 2017;14(2):96-103. doi: 10.2174/1567202613666161216150835.

22. Kumar Vr S, Darisipudi MN, Steiger S, Devarapu SK, Tato M, Kukarni OP, Mulay SR, Thomasova D, Popper B, Demleitner J, Zuchtriegel G, Reichel C, Cohen CD, Lindenmeyer MT, Liapis H, Moll S, Reid E, Stitt AW, Schott B, Gruner S, Haap W, Ebeling M, Hartmann G, Anders HJ. Cathepsin S Cleavage of Protease-Activated 
Receptor-2 on Endothelial Cells Promotes Microvascular Diabetes Complications. J Am Soc Nephrol. 2016;27(6):1635-1649. doi: 10.1681/ASN.2015020208.

23. Vouret-Craviari V, Grall D, Van Obberghen-Schilling E. Modulation of Rho GTPase activity in endothelial cells by selective proteinase-activated receptor (PAR) agonists. J Thromb Haemost. 2003;1(5):1103-1111.

24. Klarenbach SW, Chipiuk A, Nelson RC, Hollenberg MD, Murray AG. Differential actions of PAR2 and PAR1 in stimulating human endothelial cell exocytosis and permeability: the role of Rho-GTPases. Circ Res. 2003;92(3):272-278.

25. Collier, MEW, Ettelaie, C. Regulation of the incorporation of tissue factor into microparticles by serine phosphorylation of the cytoplasmic domain of tissue factor. $\mathrm{J}$. Biol. Chem. 2011;286:11977-11984. doi: 10.1074/jbc.M110.195214.

26. Ettelaie C, Collier ME, Maraveyas A, Ettelaie R. Characterization of physical properties of tissue factor-containing microvesicles and a comparison of ultracentrifuge-based recovery procedures. Journal of Extracellular Vesicles 2014;3:23592. doi: 10.3402/jev.v3.23592.

27. Collier MEW, Ettelaie C, Goult BT, Maraveyas A, Goodall AH. Investigation of the Filamin A-Dependent Mechanisms of Tissue Factor Incorporation into Microvesicles. Thromb Haemost. 2017;117(11):2034-2044. doi: 10.1160/TH17-01-0009.

28. Ettelaie C, Collier ME, Featherby S, Greenman J, Maraveyas A. Peptidyl-prolyl isomerase 1 (Pin1) preserves the phosphorylation state of tissue factor and prolongs its release within microvesicles. Biochim Biophys Acta. 2017;1865(1):12-24. doi: 10.1016/j.bbamcr.2017.09.016.

29. Burnstock G, Ralevic V. New insights into the local regulation of blood flow by perivascular nerves and endothelium. Br J Plast Surg. 1994;47(8):527-543.

30. Lucas C, Leys D. Vasodilation in spontaneous cervical artery dissection. Front Neurol Neurosci. 2005;20:64-69.

31. Wu KK, Thiagarajan P. Role of endothelium in thrombosis and hemostasis. Annu Rev Med. 1996;47:315-331.

32. Ehrlich HP, Trelstad RL, Fallon JT. Dermal vascular patterns in response to burn or freeze injury in rats. Exp Mol Pathol. 1981;34(3):281-289.

33. Enjoji S, Ohama T, Sato K. Regulation of epithelial cell tight junctions by proteaseactivated receptor 2. J Vet Med Sci. 2014;76(9):1225-1229. 
34. Jacob C, Yang PC, Darmoul D, Amadesi S, Saito T, Cottrell GS, Coelho AM, Singh P, Grady EF, Perdue M, Bunnett NW. Mast cell tryptase controls paracellular permeability of the intestine. Role of protease-activated receptor 2 and beta-arrestins. J Biol Chem. 2005;280(36):31936-31948.

35. Cenac N, Chin AC, Garcia-Villar R, Salvador-Cartier C, Ferrier L, Vergnolle N, Buret AG, Fioramonti J, Bueno L. PAR2 activation alters colonic paracellular permeability in mice via IFN-gamma-dependent and -independent pathways. J Physiol. 2004;558(3):913-925.

36. Ettelaie C, Elkeeb AM, Maraveyas A, Collier ME. p38a phosphorylates serine 258 within the cytoplasmic domain of tissue factor and prevents its incorporation into cell-derived microparticles. Biochim Biophys Acta. 2013;1833(3):613-621. doi: 10.1016/j.bbamcr.2012.11.010.

37. Camerer E, Huang W, Coughlin SR. Tissue factor- and factor X-dependent activation of protease-activated receptor 2 by factor VIla. Proc Natl Acad Sci U S A. 2000;97(10):5255-5260.

38. Camerer E, Kataoka H, Kahn M, Lease K, Coughlin SR. Genetic evidence that proteaseactivated receptors mediate factor $\mathrm{Xa}$ signaling in endothelial cells. J Biol Chem. 2002;277(18):16081-16087.

39. Sen P, Gopalakrishnan R, Kothari H, Keshava S, Clark CA, Esmon CT, Pendurthi UR, Rao LV. Factor VIla bound to endothelial cell protein $C$ receptor activates protease activated receptor-1 and mediates cell signaling and barrier protection. Blood. 2011;117(11):3199-3208. doi: 10.1182/blood-2010-09-310706.

40. Sundaram J, Keshava S, Gopalakrishnan R, Esmon CT, Pendurthi UR, Rao LV. Factor VIla binding to endothelial cell protein $\mathrm{C}$ receptor protects vascular barrier integrity in vivo. J Thromb Haemost. 2014;12(5):690-700.

41. Malik AB, Fenton JW 2nd. Thrombin-mediated increase in vascular endothelialpermeability. Semin Thromb Hemost. 1992;18(2):193-9.

42. Kondo $\mathrm{N}$, Ogawa $\mathrm{M}$, Wada $\mathrm{H}$, Nishikawa $\mathrm{S}$. Thrombin induces rapid disassembly of claudin-5 from the tight junction of endothelial cells. Exp Cell Res. 2009;315(17):28792887. doi: 10.1016/j.yexcr.2009.07.031.

43. Riewald M, Petrovan RJ, Donner A, Mueller BM, Ruf W. Activation of endothelial cell protease activated receptor 1 by the protein C pathway. Science. 2002;296(5574):18801882. 
44. O'Brien PJ, Prevost N, Molino M, Hollinger MK, Woolkalis MJ, Woulfe DS, Brass LF. Thrombin responses in human endothelial cells. Contributions from receptors other than PAR1 include the transactivation of PAR2 by thrombin-cleaved PAR1. J Biol Chem. 2000;275(18):13502-13509.

45. Liu LW, Vu TK, Esmon CT, Coughlin SR. The region of the thrombin receptor resembling hirudin binds to thrombin and alters enzyme specificity. $\mathrm{J}$ Biol Chem. 1991;266(26):16977-16980.

46. Aschner JL, Lennon JM, Fenton JW 2nd, Aschner M, Malik AB. Enzymatic activity is necessary for thrombin-mediated increase in endothelial permeability. Am J Physiol. 1990;259(4):L270-5.

47. Kothari H, Pendurthi UR, Rao LV. Analysis of tissue factor expression in various cell model systems: cryptic vs. active. J Thromb Haemost. 2013;11(7):1353-1363. doi: 10.1111/jth.12272.

48. Bach RR. Tissue factor encryption. Arterioscler Thromb Vasc Biol. 2006;26(3):456-461.

49. Butenas S, Amblo-Krudysz J, Mann KG. Posttranslational modifications of tissue factor. Front Biosci (Elite Ed). 2012;4:381-391.

50. Egorina EM, Sovershaev MA, Osterud B. Regulation of tissue factor procoagulant activity by post-translational modifications. Thromb Res. 2008;122(6):831-837. doi: 10.1016/j.thromres.2007.11.004.

51. Wolberg AS, Monroe DM, Roberts HR, Hoffman MR. Tissue factor de-encryption: ionophore treatment induces changes in tissue factor activity by phosphatidylserinedependent and -independent mechanisms. Blood Coagul Fibrinolysis. 1999;10(4):201210.

52. Chen VM, Hogg PJ. Encryption and decryption of tissue factor. J Thromb Haemost. 2013;11 Suppl 1:277-284. doi: 10.1111/jth.12228.

53. Liang HP, Kerschen EJ, Hernandez I, Basu S, Zogg M, Botros F, Jia S, Hessner MJ, Griffin JH, Ruf W, Weiler H. EPCR-dependent PAR2 activation by the blood coagulation initiation complex regulates LPS-triggered interferon responses in mice. Blood. 2015;125(18):2845-54. doi: 10.1182/blood-2014-11-610717.

54. Yuan Q, Zhang D, Wu S, Yu J, Yu L, Sun Y, Du Z, Li Z, Zhou L, Wu X, Hu J. FVIla prevents the progressive hemorrhaging of a brain contusion by protecting microvessels via formation of the TF-FVIla-FXa complex. Neuroscience. 2017;348:114-125. doi: 10.1016/j.neuroscience.2017.02.020. 
55. Collier ME, Mah PM, Xiao Y, Maraveyas A, Ettelaie C. Microparticle-associated tissue factor is recycled by endothelial cells resulting in enhanced surface tissue factor activity. Thromb Haemost. 2013;110(5):966-976. doi:10.1160/TH13-01-0055.

56. Chironi GN, Boulanger CM, Simon A, Dignat-George F, Freyssinet JM, Tedgui A. Endothelial microparticles in diseases. Cell Tissue Res. 2009;335(1):143-151. doi: 10.1007/s00441-008-0710-9.

57. Benedict CR, Pakala R, Willerson JT. Endothelial-dependent procoagulant and anticoagulant mechanisms. Recent advances in understanding. Tex Heart Inst J. 1994;21(1):86-90. 


\section{Figure Legends}

Fig. 1. Increase in endothelial permeability on PAR2 activation. Monolayers of HCAEC (A) and HDBEC (B) were prepared by culturing the cells $\left(6 \times 10^{4}\right)$ in gelatin-coated Transwell chambers for 4 days. The monolayers were washed twice with PBS and adapted to serumfree endothelial medium. Blue dextran was added to a final concentration of $1 \mu \mathrm{g} / \mathrm{ml}$ to the upper chamber of each Transwell. Sets of cells were activated with PAR2-AP $(20 \mu \mathrm{M})$, PAR1-AP $(20 \mu \mathrm{M})$ or VEGF-A (25 $\mathrm{ng} / \mathrm{ml})$ added to the upper chambers. The samples were incubated at $37^{\circ} \mathrm{C}$ for up to $60 \mathrm{~min}$. Aliquots of the media $(200 \mu \mathrm{l})$ were removed from the bottom chamber and the absorption measured at $584 \mathrm{~nm}$ measured. $\left(n=4 ;{ }^{*}=p<0.05\right)$

Fig. 2. Increase in endothelial permeability in response to fXa. Monolayers of HCAEC (A) and HDBEC (B) were prepared by culturing the cells $\left(6 \times 10^{4}\right)$ in gelatin-coated Transwell chambers for 4 days. The monolayers were washed twice with PBS and adapted to serumfree endothelial medium. Blue dextran was added to a final concentration of $1 \mathrm{ng} / \mathrm{ml}$ to the upper chamber of each Transwell. Sets of cells were activated with factor Xa (0-10 nM) added to the upper chambers. The samples were incubated at $37^{\circ} \mathrm{C}$ for up to $60 \mathrm{~min}$. Aliquots of the media $(200 \mu \mathrm{l})$ were removed from the bottom chamber and the absorption measured at $584 \mathrm{~nm}$ measured. $(n=4 ; *=p<0.05)$

Fig. 3. Therapeutic concentrations of Rivaroxaban fully inhibit the activity of $f \times a$. Samples of fXa (10 nM) were incubated with Rivaroxaban $(0.06$ and $0.6 \mu \mathrm{g} / \mathrm{ml})$ or DMSO vehicle. The samples were incubated in the presence of a fXa substrate $(0.2 \mathrm{mM})$ and the fXa protease activity evaluated by measuring the absorptions at $405 \mathrm{~nm} .\left(n=3 ;{ }^{*}=p<0.05\right)$

Fig. 4. The increase in endothelial permeability is dependent on fXa protease activity. Monolayers of $\operatorname{HCAEC}(\mathrm{A})$ and $\operatorname{HDBEC}(\mathrm{B})$ were prepared by culturing the cells $\left(6 \times 10^{4}\right)$ in gelatin-coated Transwell chambers for 4 days. The monolayers were washed twice with PBS and adapted to serum-free endothelial medium. Blue dextran was added to a final concentration of $1 \mu \mathrm{g} / \mathrm{ml}$ to the upper chamber of each Transwell. Sets of cells were activated with factor $\mathrm{Xa}(10 \mathrm{nM})$ in the presence of Rivaroxaban $(0.06$ and $0.6 \mu \mathrm{g} / \mathrm{ml})$ or 
DMSO vehicle. The samples were incubated at $37^{\circ} \mathrm{C}$ and the effect of Rivaroxaban was also monitored at $60 \mathrm{~min}(\mathrm{~A})$ and also monitored at $30 \mathrm{~min}(\mathrm{~B})$. Aliquots of the media (200 $\mu \mathrm{l})$ were removed from the bottom chamber and the absorption measured at $584 \mathrm{~nm}$ measured. $(n=4 ; *=p<0.05)$

Fig. 5. The increase in endothelial permeability is mediated through PAR2 activation. Monolayers of $\operatorname{HCAEC}(A)$ and $\operatorname{HDBEC}(B)$ were prepared by culturing the cells $\left(6 \times 10^{4}\right)$ in gelatin-coated Transwell chambers for 4 days. The monolayers were washed twice with PBS and adapted to serum-free endothelial medium in the presence or absence of PAR2 and PAR1 blocking antibodies (SAM11 and ATAP2 respectively). Blue dextran was added to a final concentration of $1 \mu \mathrm{g} / \mathrm{ml}$ to the upper chamber of each Transwell. Sets of cells were activated with factor $\mathrm{Xa}(10 \mathrm{nM})$ added to the upper chambers. The samples were incubated at $37^{\circ} \mathrm{C}$ for up to $60 \mathrm{~min}$. Aliquots of the media $(200 \mu \mathrm{l})$ were removed from the bottom chamber and the absorption measured at $584 \mathrm{~nm}$ measured. $\left(n=5 ;{ }^{*}=p<0.05\right)$

Fig. 6. PAR2-mediated increase in endothelial permeability occurs in response to fXa but not TF-fVIla. Monolayers of HCAEC were prepared by culturing the cells $\left(6 \times 10^{4}\right)$ in gelatincoated Transwell chambers for 4 days. The monolayers were washed twice with PBS and adapted to serum-free endothelial medium. Blue dextran was added to a final concentration of $1 \mathrm{ng} / \mathrm{ml}$ to the upper chamber of each Transwell. A) Sets of cells were incubated with purified TF-containing microvesicles or with recombinant TF $(1 \mathrm{U} / \mathrm{ml})$, in the presence or absence of $\mathrm{fVIIa}(5 \mathrm{nM})$, and compared to treatment with $\mathrm{fXa}(10 \mathrm{nM})$ alone. The samples were incubated at $37^{\circ} \mathrm{C}$ and examined at 60 or $120 \mathrm{~min}$. Aliquots of the media (200 $\left.\mu \mathrm{l}\right)$ were removed from the bottom chamber and the absorption measured at $584 \mathrm{~nm}$ measured. $(n=$ $\left.3 ;^{*}=p<0.05\right)$. B) Sets of cells were incubated with purified TF-containing microvesicles or with recombinant TF $(1 \mathrm{U} / \mathrm{ml})$, in the presence of fVIla $(5 \mathrm{nM})$, and in the presence or absence of $\mathrm{fXa}(10 \mathrm{nM})$. The samples were incubated at $37^{\circ} \mathrm{C}$ for up to $60 \mathrm{~min}$. Aliquots of the media $(200 \mu \mathrm{l})$ were removed from the bottom chamber and the absorption measured at $584 \mathrm{~nm}$ measured. $(n=3)$. 
Figure 1

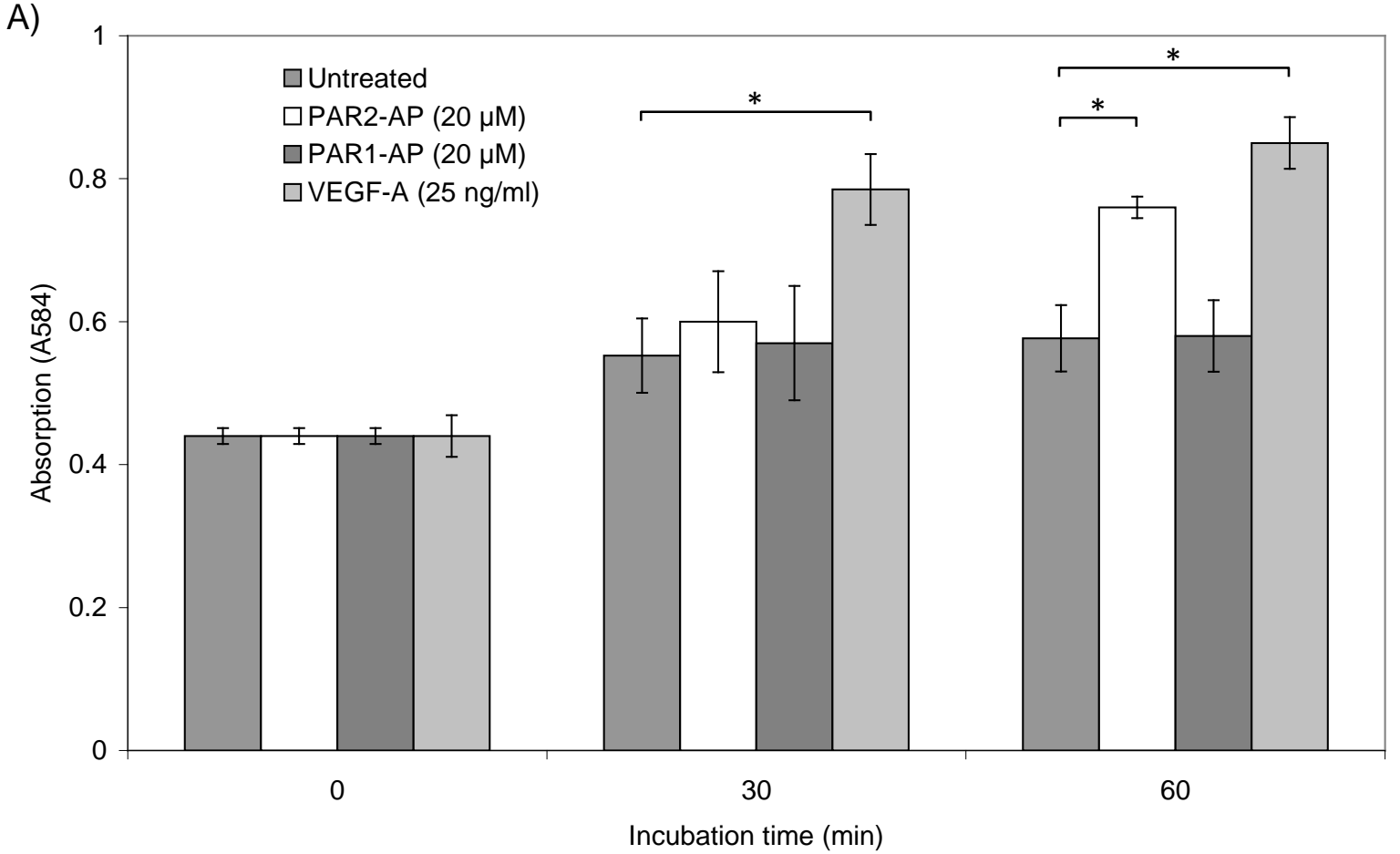

B)

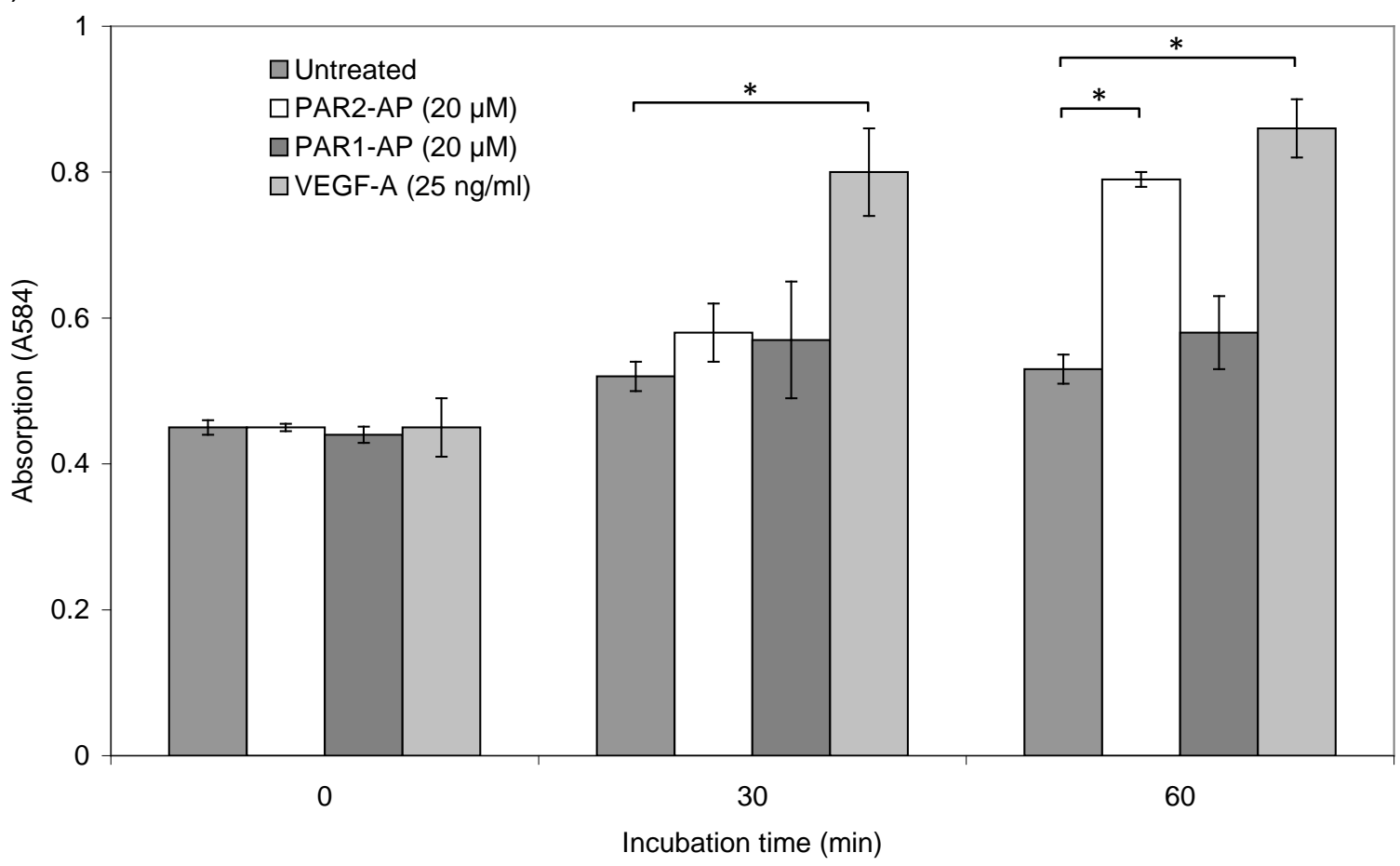


Figure 2

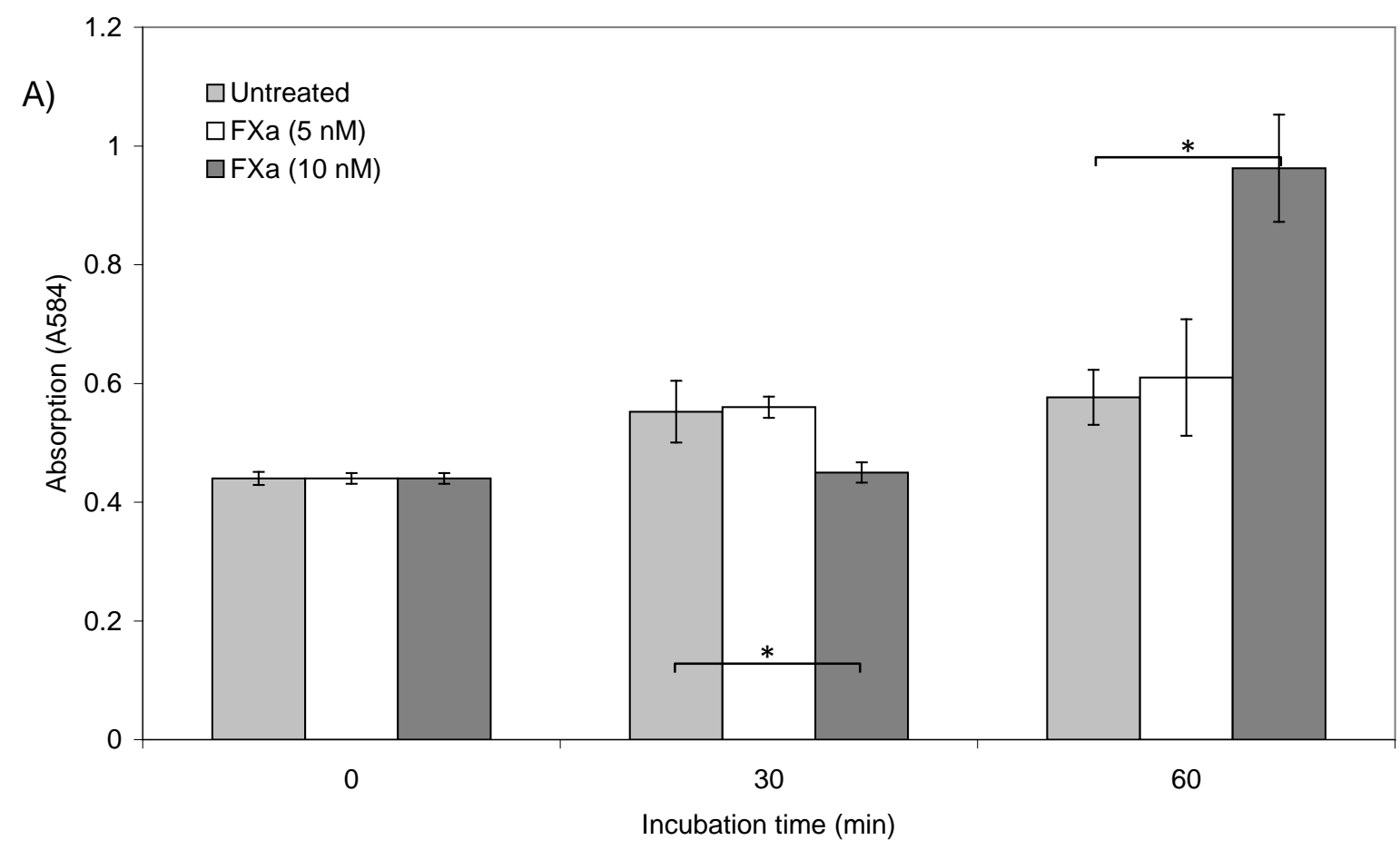

B)

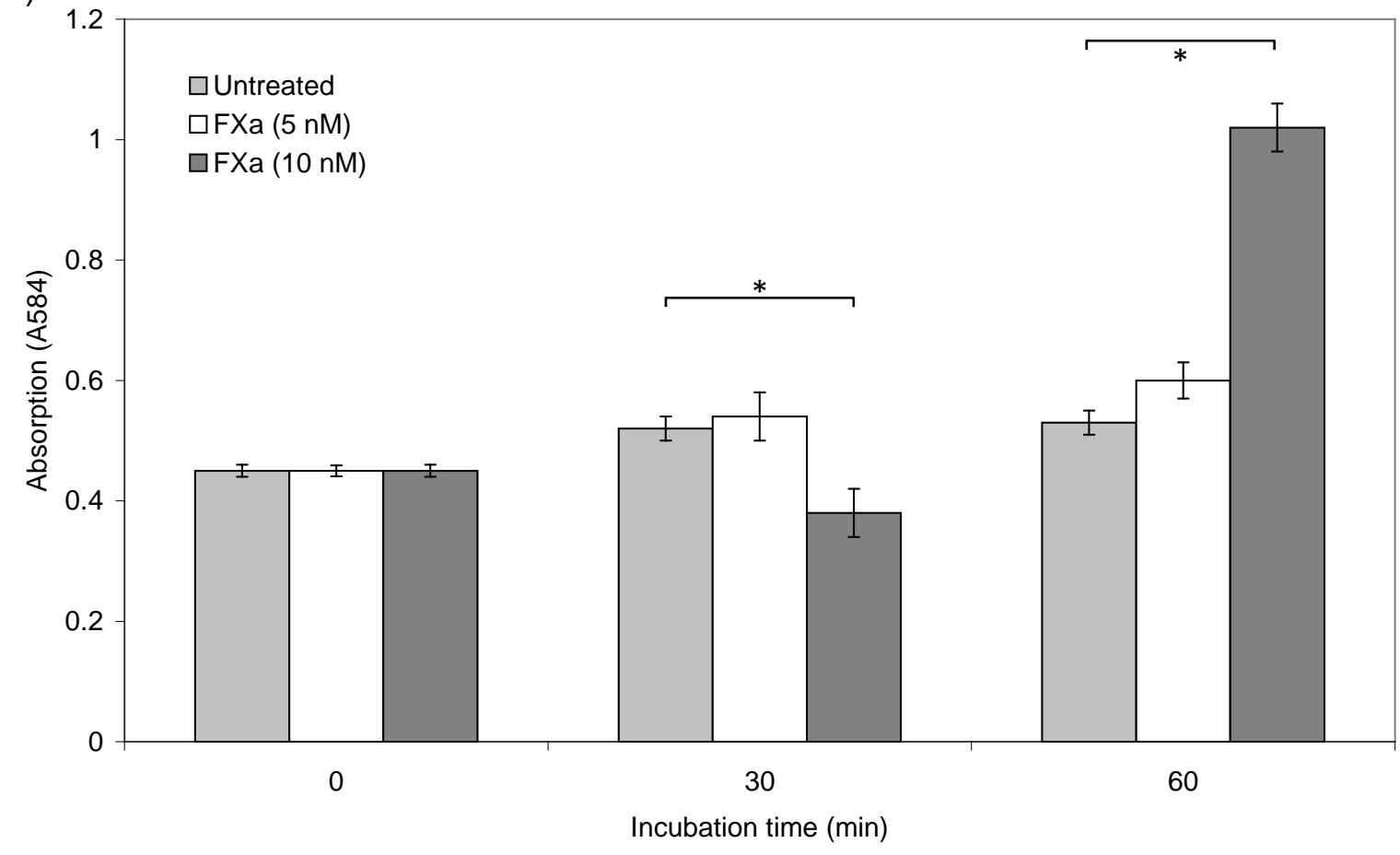


Figure 3

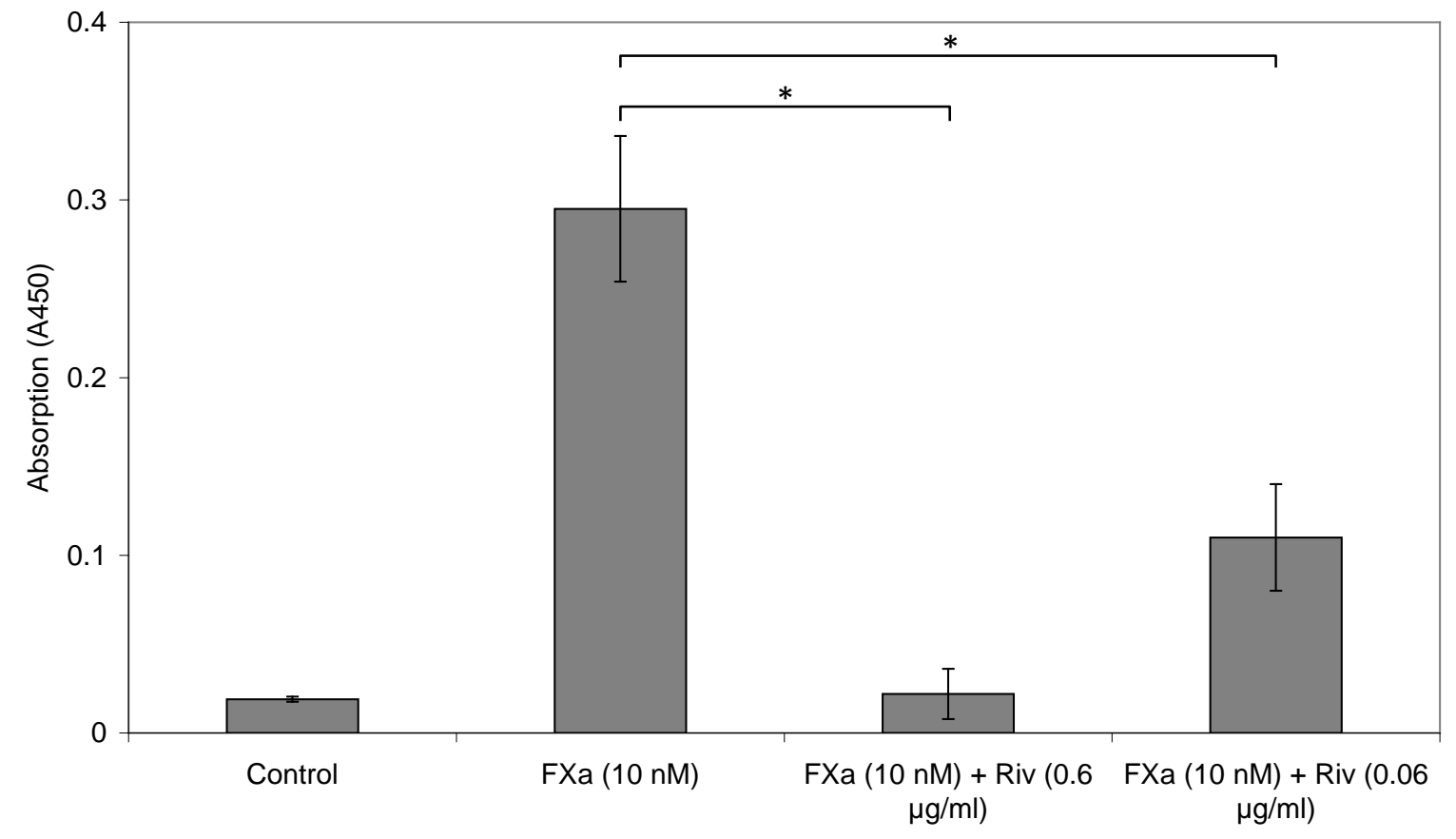


Figure 4

A)

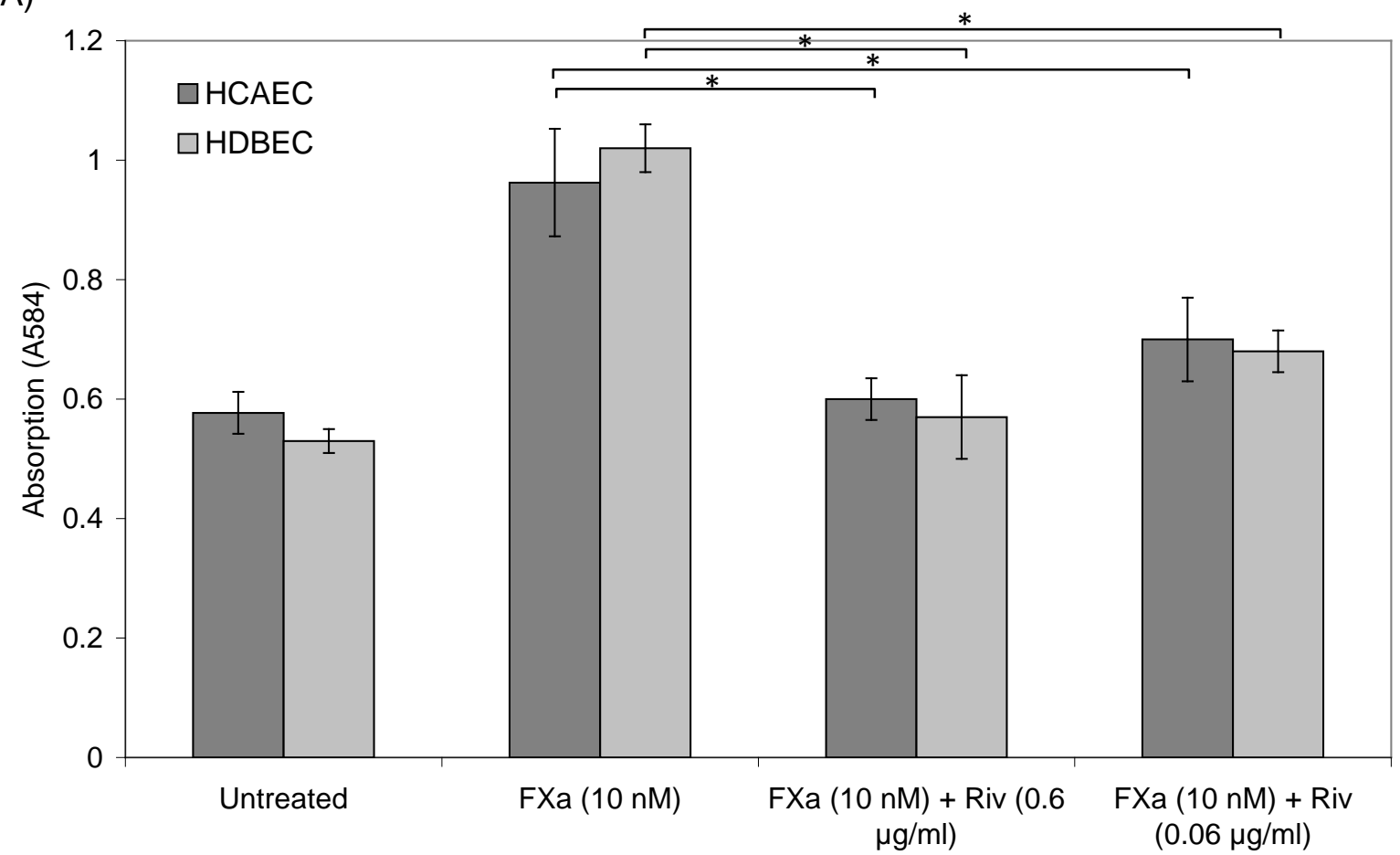

B)

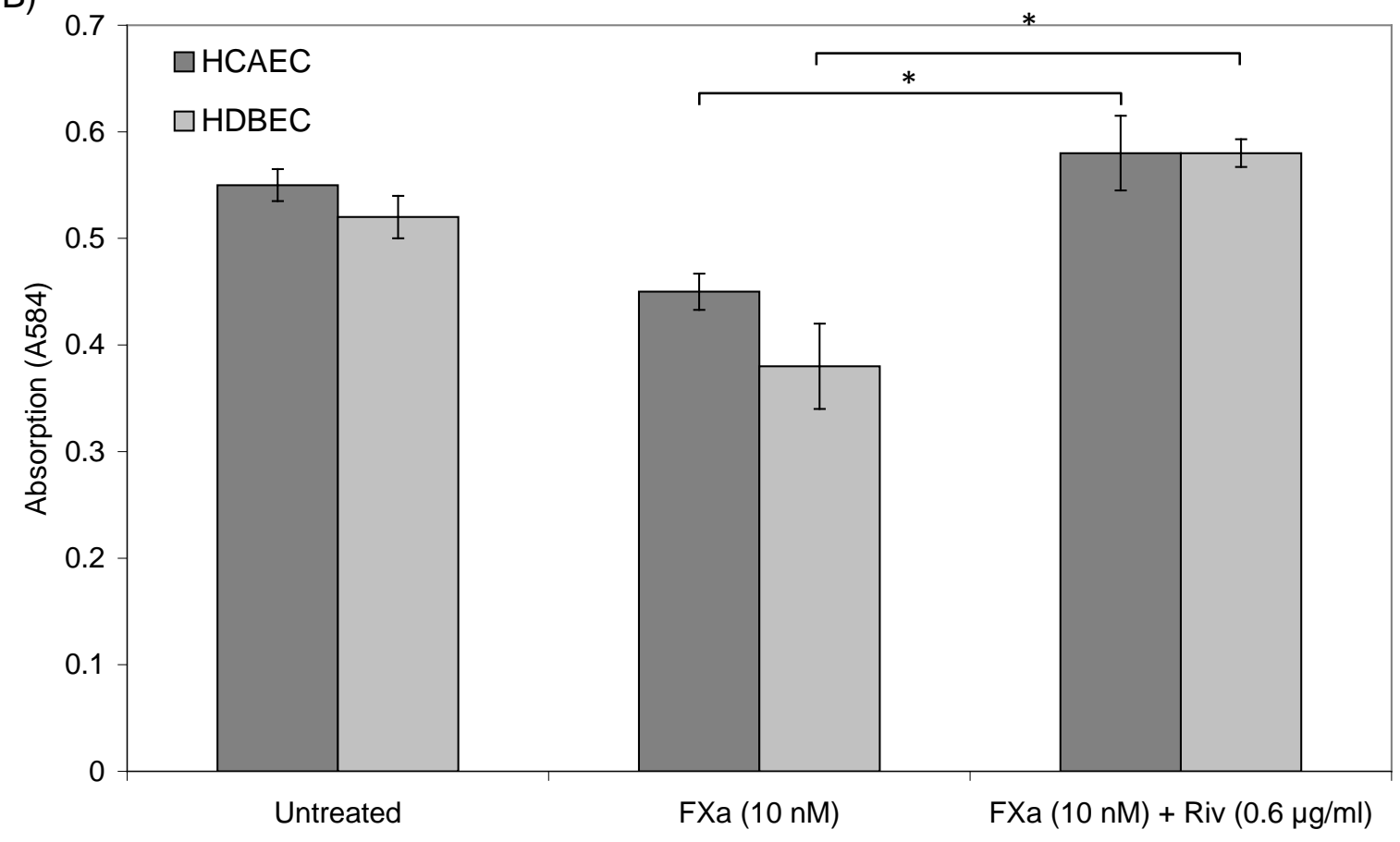


Figure 5

A)

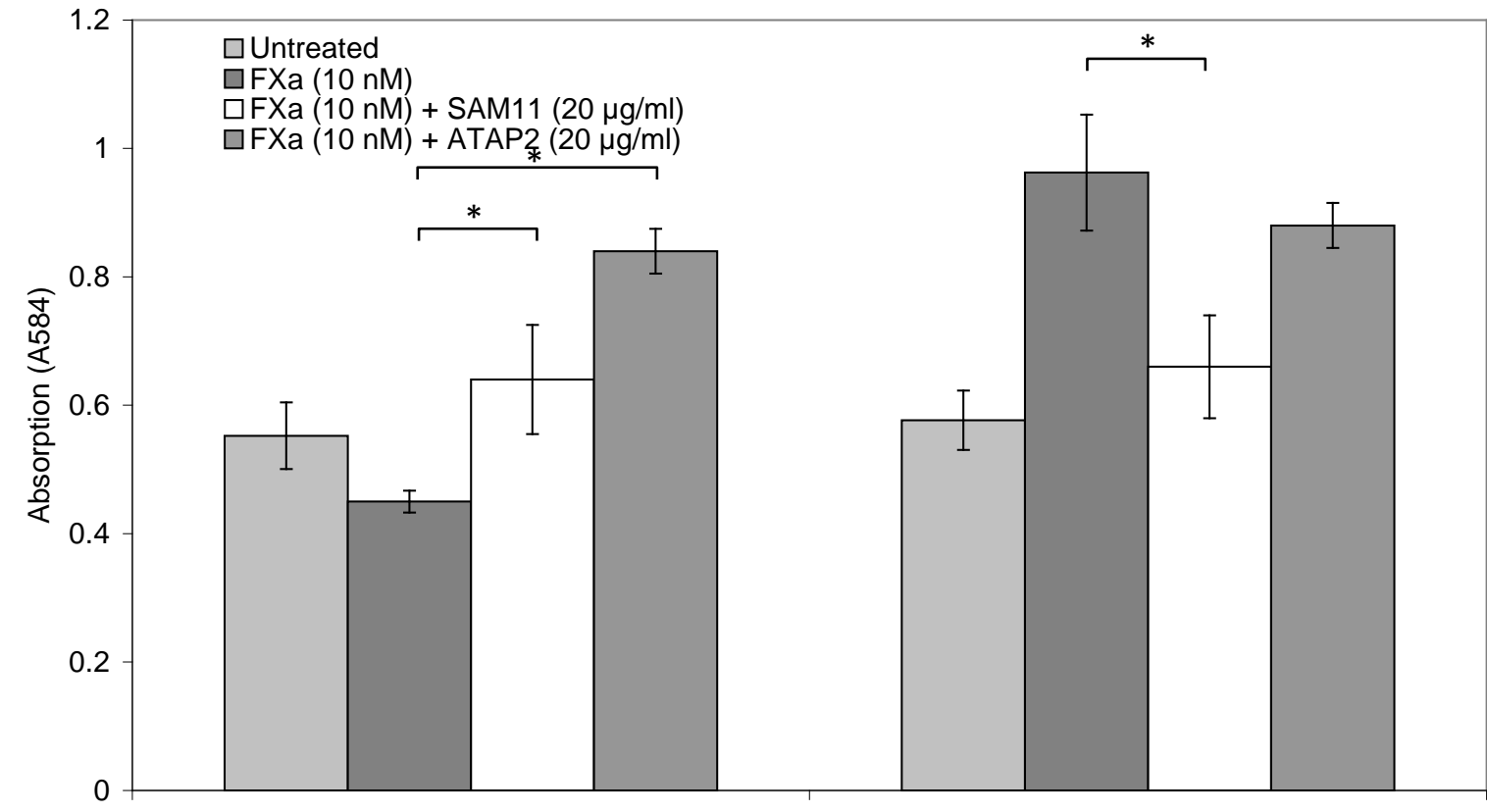

B)

30

60

Incubation time (min)

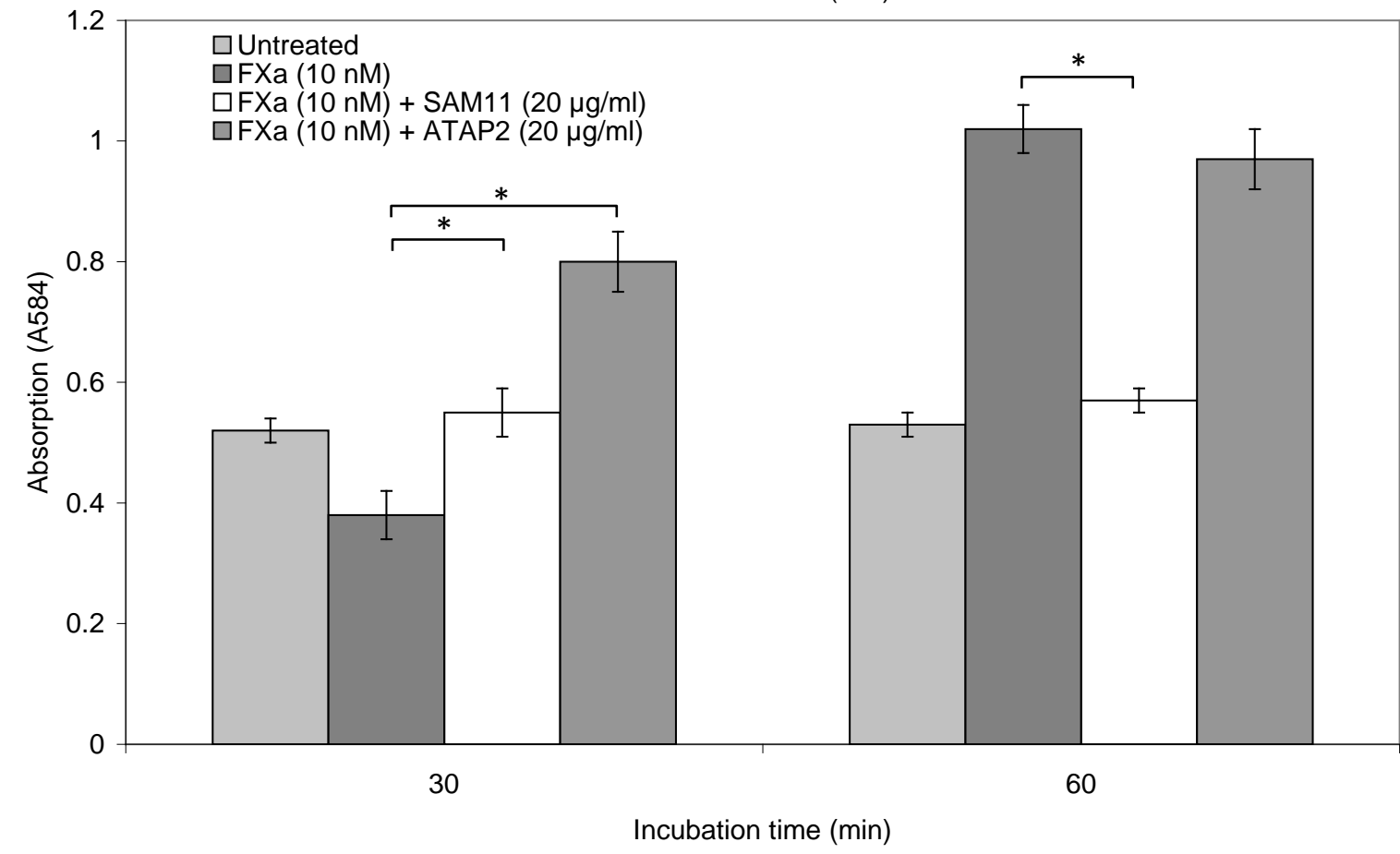


Figure 6

A)

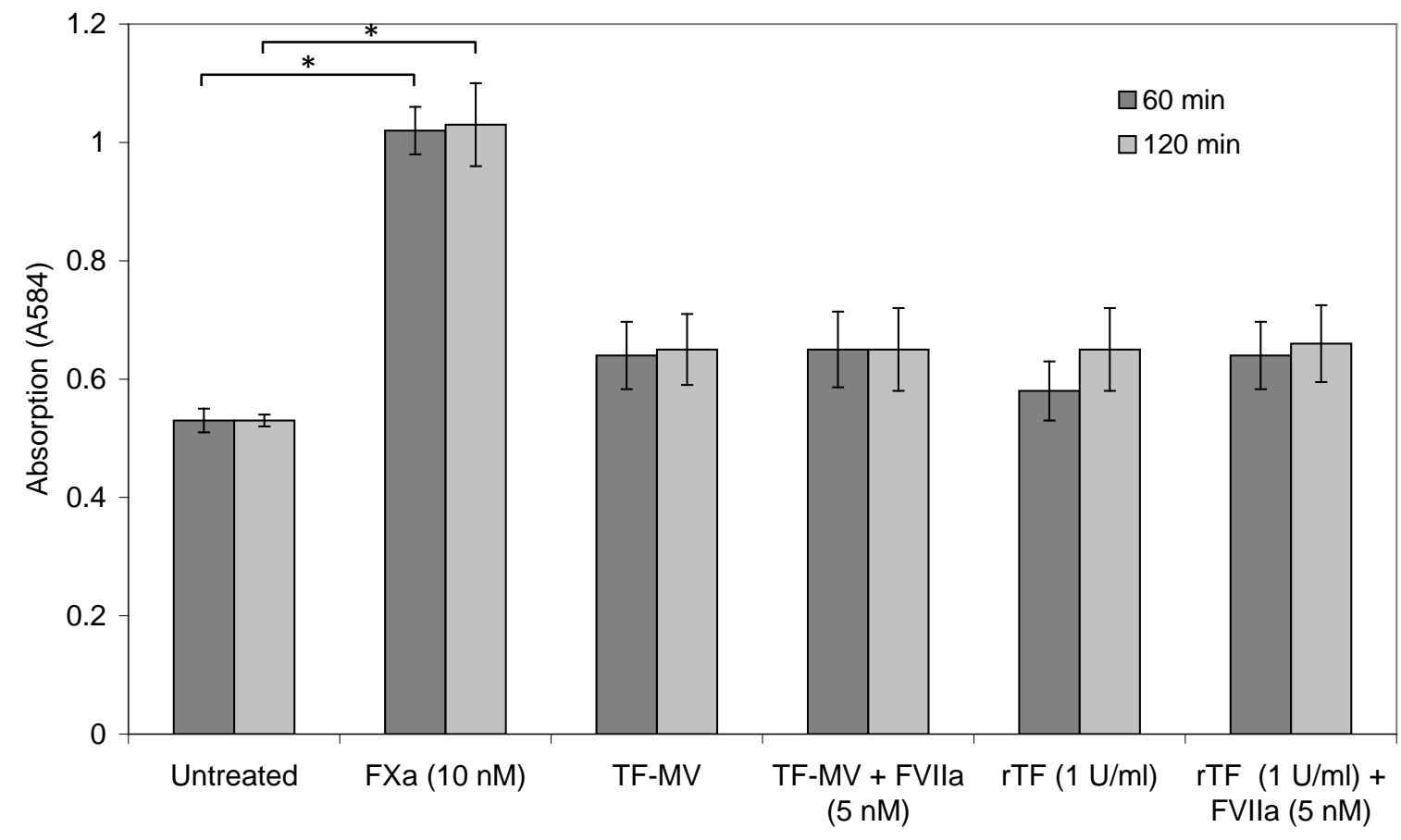

B)

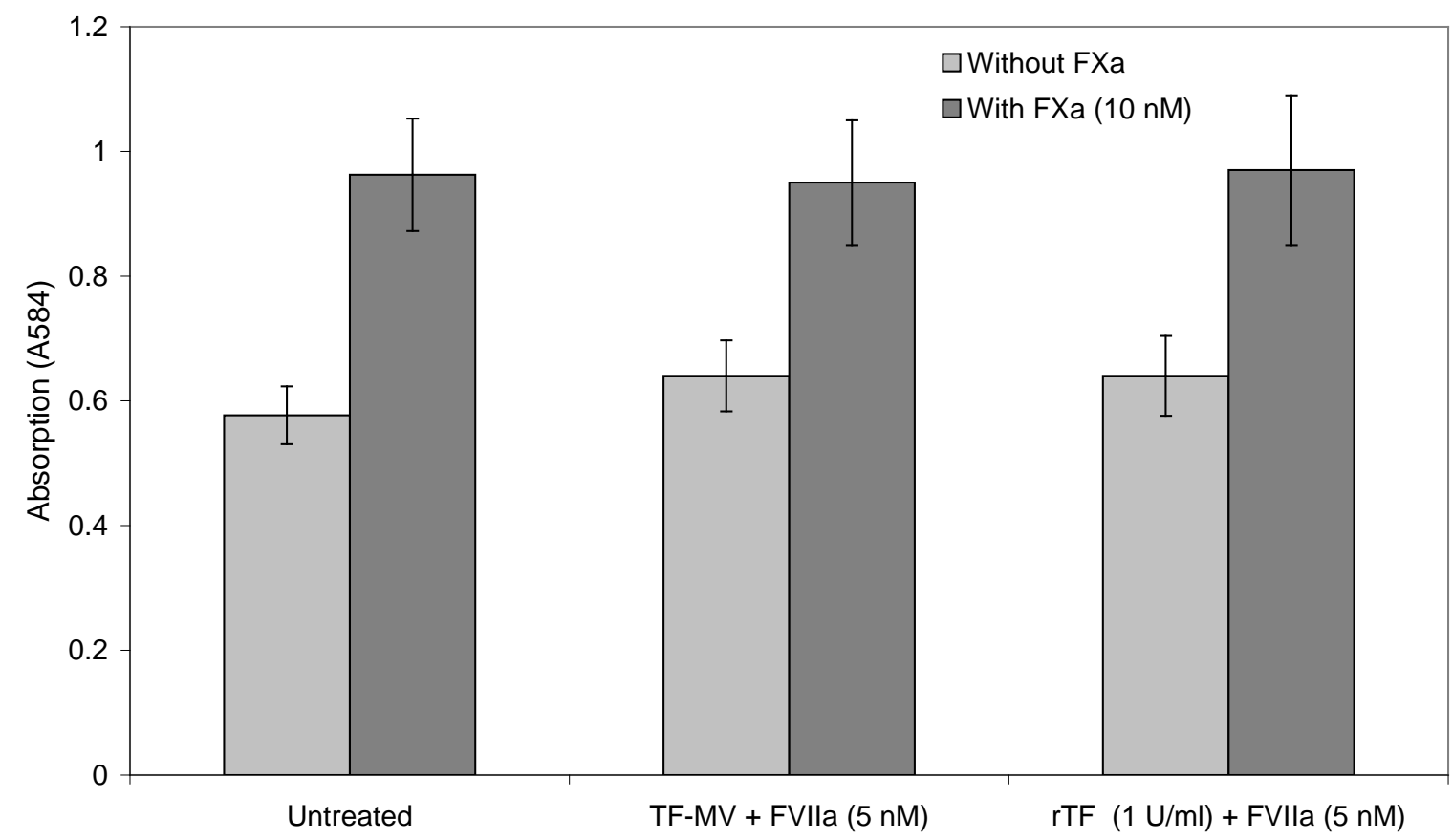

